\title{
A Most Curious Lack of Curiosity: Global Unions as the Missing Link in Labour Movement Studies
}

\author{
David Huxtable University of Victoria
}

\begin{abstract}
Résumé
Le présent article s'inspire de la contribution de l'auteur au panel pour les sujets de recherche sur la gauche aujourd'hui, constitué lors du congrès de 2006 de la Société des études socialistes. On y constate, malgré le renouveau d'intérêt universitaire pour les mouvements syndicaux, un manque de recherche contemporaine sur les confédérations syndicales internationales déjà existantes et sur leur rôle potentiel à l'avenir. L'objectif de l'article est d'intéresser les universitaires de gauche à un projet de recherche futur sur les organisations réunies dans le groupement Global Unions et notamment sur la Confédération syndicale internationale, récemment créée. Après avoir esquissé l'histoire de ces organisations et leurs activités, l'auteur suggère une série de questions pouvant s'avérer intéressantes pour ceux que préoccupe l'orientation qu'adopteront à l'avenir les organisations syndicales au niveau international.
\end{abstract}

\begin{abstract}
This paper is based on the author's contribution to 'The Research Agenda for the Left Today' panel held during the Society for Socialist Studies 2006 conference.1 It argues that, despite the recent renewal of academic interest in labour movements, there is a gap in contemporary research on organized labour around the existence of and potential future role for actually existing global trade unions. The purpose of this paper is to spark an interest amongst left academics in a future research project on the organizations which comprise the recently created Council of Global Unions, and in particular the recently created International Trade Union Confederation. After a brief introduction to the history of these organizations and an outline of their activities, the author offers a number of questions that may prove interesting for those concerned about the future direction of organized labour at the global level.
\end{abstract}

Who precisely would 'spontaneously' move against the unregulated disembedded market system and why? (Munck, 2004: 253)

1 The author's participation at this conference was made possible through funding generously provided by the Society for Socialist Studies, for which he is extremely grateful. 


\section{A Most Curious Lack of Curiosity: Global Unions as the \\ Missing Link in Labour Movement Studies}

\section{Introduction}

While the interest of socialist academics in trade unions appeared to wane in the closing decades of the 20th century, dramatic events, such as the 1999 WTO demonstrations in Seattle, have stimulated a resurgence in academic interest since the turn of the current century. In a 2005 issue of Work and Occupations, Turner (2005) calls for a research agenda on union revitalization that includes the local, national and international level. However, the accompanying papers in that addition paid scant attention to existing international trade union federations; a common oversight.

When trade unions are examined in an 'international' light, it is usually comparative in nature. Thus we have excellent research that compares across different locations recent changes in union structure (Gamble, 2007; Sverke, 1997). There is also solid research that examines the different labour strategies employed around the world (Munck and Waterman, 1999), as well as the difference in outcomes when unions employ similar strategies in different locations (Chun, 2005). Finally, there is also a growing body of literature on the informal global networks developing between local unions (Stillerman, 2003; Munck and Waterman, 1999; Waterman, 2001; 2004; Waterman and Wills, 2001; Castree, 2002).

The body of literature that is largely missing is that which would rigorously examine existing global or international union organizations and their current activities.2 Given the importance of 'internationalism' in socialist strategy, such an oversight is particularly glaring amongst researchers concerned with socialist or transformative politics. The argument presented here is that academics concerned with socialist transformation can no longer dismiss the organizations of international trade unionism as a cold-war relic; and furthermore, that a research program is needed that rigorously interrogates the contemporary organizations of international labour, their goals, failures and successes, as well as their relationships with other social movement organizations.

The purpose of this paper is to briefly reintroduce the existing international trade union organizations, outline their recent activities and ask a number of questions that may contribute to defining the contours of a research agenda that places these institutions under a microscope. It will unfold in the following manner: after a brief outline of the history of international trade unionism, two broad areas are examined. The first outlines what appear to be the goals of the dominant global union organizations: the International Trade Union Confederation (ITUC) and affiliated Global Union Federations (GUF), which together make up the umbrella group Global Unions (GU).The second area examined involves the changing relational dynamics both within the international trade union movement and between these union federations and the global social justice community. The paper

2 There are some notable exceptions to this. See Gumbrell-McCormick (2004a; 2004b; 2006), Greenwood and Webb (1911) and Waterman and Wills (2001). Finally, there is a very well researched history of the ICFTU that has been recently published. See Carew, Dreyfus, Goethem and GumbrellMcCormick (2000). 


\section{A Most Curious Lack of Curiosity: Global Unions as the Missing Link in Labour Movement Studies}

will conclude with a modest outline of questions that may be of interest to left-oriented researchers and a brief argument as to why the study of international union organizations should be seen as particularly important for researchers concerned with social change.

\section{A Brief History of International Trade Unionism}

The history of organized labour internationalism can be traced back to the First International Workingmen's Association of 1864-1876, although there were various "calls and programs for international action" as far back as the 1830's (Stevis, 1998: 54). Issues of international solidarity involved both practical concerns, such as the fear of scab labour being imported from other countries, and more philosophical ones, such as Polish independence (Windmuller, 1980: 15-16). It was hardly a global project, being exclusively European in its make-up, but the membership did represent those labouring people touched by a capitalist labour market. The history of this organization, as well as those which followed it such as the Socialist International (1889-1916) and the Communist International (1919-1943), is both beyond the scope of this paper and well covered elsewhere. 3 Nonetheless it is important to recognize these organizations and their profound impact on the contemporary international trade union movement as the ideological battles which raged within these organizations were cited by early trade union leaders as a reason for establishing exclusively trade union organizations at the international level (Windmuller, 1969: 4).

Concurrent with the development of the Second International was the early development of the first International Trade Secretariats (ITSs) and the International Federation of Trade Unions (IFTU). The ITSs, now known as Global Union Federations (GUFs), established themselves as union federations attached to specific trades or industries. While many have since disappeared or merged into larger composites, some of the first to be established, such as the Metal Workers Federation and the Transport Workers' Federation, established in 1893 and 1898 respectively, continue to exist. As outlined below, they played an important role in shaping the international labour movement, and in particular the split between communist and non-communist organizations in the post-war period.

In 1903, the International Secretariat of Trade Union Centres was established, although it changed its name to the International Federation of Trade Unions (IFTU) in 1913. The IFTU was the precursor to both the World Federation of Trade Unions (WFTU) and the International Confederation of Free Trade Unions (ICFTU) (Busch 1983; Windmuller 1969). What distinguished the IFTU from the trade secretariats was the nature of the organizations that made up its membership. Whereas ITS membership involved trade unions in specific industries, the IFTU membership was another step removed from individual union members, as its membership was comprised of the national union confederations such as the British or German Trade Union Confederations, which are

3 For a thorough early history of the Internationals refer to the multi-volume work by Braunthal (1966). See also Cole (1953). 
themselves confederations of independent unions. This is still the case today with the International Trade Union Confederation (ITUC).

The World Congress of Labour began in 1920 as the International Federation of Christian Trade Unions. As its original name suggests, the WCL was initially an exclusively Christian union federation, and until the post-war period, its membership was primarily Western European. Within the organization were industry specific caucuses and regional organizations. While a number of its member organizations were traditional trade unions, its membership was also made up of a number of "fraternal associations of workers who form minority caucuses" within other unions (Windmuller, 1969: 30). During the postwar period, the organization sought to expand its presence globally and in 1968 it changed its name to the World Congress of Labour, officially opening up its membership to all faith-based labour organizations (Windmuller, 1969: 27). WCL membership world-wide was always a fraction of its rivals. However, its Latin American regional organization, the Latin American Federation of Christian Trade Unions (CLASC) was for a time a strong rival to the Inter American Regional Organisation of Workers (ORIT), the International Confederation of Free Trade Unions (ICFTU) affiliate in the Americas. In 2006, the WCL officially dissolved itself and the vast majority of its member organizations joined ICFTU members in creating a new international trade union organization, the International Trade Union Confederation (ITUC). This merger is covered in more depth later in this paper.

The IFTU, established in 1903, did not survive the Second World War. By 1942, trade union leaders representing a wide political spectrum and geographic area began to organize for a post-war international labour movement. Walter Schevenels, an active participant in and subsequent chronicler of the international trade union movement, suggests that these leaders felt a profound sense of history at this time. Many international labour leaders, he claims, felt that the failure of the League of Nations to avoid war and the failure of the International Labour Organization to produce a more human capitalism were at least partially attributable to the divisions between the communist, socialist and Christian movements that had produced a vacuum in working class leadership (Schevenels, 1956).

In February of 1945, a new organization was founded by the central labour organizations of both sides of the war, save the American Federation of Labor. Windmuller suggests that the WFTU rode a wave of post-war unity from 1945 to 1949 and "dominated international trade unionism" (1969: 10). However, this concord was only formal and from its inception the WFTU was divided on a number of issues that had previously prevented unity amongst international labour leaders.

Particularly contentious was the resistance of non-communist trade union leaders to the efforts of communist leaders who sought to utilize trade union struggles in the build up 


\section{A Most Curious Lack of Curiosity: Global Unions as the Missing Link in Labour Movement Studies}

to world-wide proletarian revolution. Furthermore, there was a perception (not entirely inaccurate) amongst trade union leaders from the West that Eastern-bloc unions were merely a tool of the Communist International (Comintern) and Russian foreign policy. Closely related to this was the issue of ITS autonomy from the new organization. Leaders within WFTU who aligned themselves with the Comintern sought to bring the ITSs under the WFTU umbrella as departments, with little control over their own budgets, a position which the Transport and Metalworkers Federations resisted. Such battles over the political autonomy of trade unions can be traced back at least as far as the creation of the ISNTUC. The creation of this trade union secretariat can be seen as a response of trade union leaders to the attempts of Russian and German Social Democrat leaders to subsume trade union issues under a broader political program (Milner, 1988). Given the importance of political autonomy for trade union leaders, it is no surprise that this was the issue cited by British, American and Dutch trade union leaders as their motivation for leaving the WFTU in 1949 (Carew, 1984).

However, the public face of the division between communist-supporting union leaders and anti-communist leaders, both within the international trade union movement, as well as within national union federations in Western Europe, was the battle over the Marshal Plan. While the plan for US led post-war reconstruction in Europe received strong support from most non-communist trade union leaders, labour leaders aligned with the Comintern saw it as an example of US imperialism and organized against it. In France and Italy communists exacerbated existing political tensions by organizing general strikes in response to the Marshal Plan. At the international level, efforts by the WFTU leadership to neutralize, or at least contain this division, failed to prevent the British and American leadership from organizing the European Recovery Program Trade Union Advisory Council (ERPTUAC) (Lorwin, 1953).

Most likely, it was through the ERPTUAC that non-communist European trade unionists, as well as the American CIO, negotiated the creation of the International Confederation of Free Trade Unions in December of 1949 (Carew, 1984). The ICFTU immediately entered into a formal relationship with the ITSs, although the latter maintained their independence. The split formalized the division between communist and non-communist labour movements and reduced the WFTU and ICFTU to little more than a new front in the Cold War between the U.S. and the Soviet Union. For the rest of the century, international trade union politics would be characterized by a three way competition now established between the WFTU, the ICFTU and affiliated ITSs, and the International Federation of Christian Trade Unions, which renamed itself the World Congress of Labour (WCL) in 1968. Later in this paper, the end of this competition is identified as one of a number of promising developments in international trade unionism. 
The rest of this paper focuses on the ICFTU as it is very clear, and has been for some time, that the ICFTU has dominated the international trade union movement for the past three decades. Prior to its dissolution, the World Confederation of Labour (WCL) claimed a membership of 26 million workers in 144 different unions from 116 countries. The International Confederation of Free Trade Unions (ICFTU) claimed a membership of 155 million workers in 241 'affiliated organizations' from 156 countries. The World Federation of Trade Unions (WFTU) claimed 129 million members in more than 130 countries, although it is difficult to assess the WFTU numbers as their membership is not public (ICTUR, 2005). Furthermore, the collapse of the Soviet Bloc dramatically reduced the WFTU's membership, as a number of former members left for the ICFTU.4

Disparity in the level of activity is as important as membership numbers in ascertaining the relative significance of the three competing organizations. The response of the WFTU to the rise of transnational corporations has been largely symbolic, perhaps due to the limited intrusion of TNCs in the communist bloc economies and the relative weakness of those member organizations from outside of the Soviet Bloc and China. The WCL has been equally symbolic in its action, largely due to the relative weakness of the organization, which is largely made up of 'dual card' organizations and factional groups rather than national trade union centrals. In contrast, the ICFTU and its affiliates have sought to confront TNCs indirectly through extensive lobbying at the international level for the past three decades, and directly through attempts at global collective bargaining. While the results of these efforts have been at best uneven, and at worst completely ineffective, nonetheless, it is the case that the ICFTU and its new manifestation, the ITUC, have been far more active than the other two international organizations in their confrontation with capital and have dominated the international trade union movement for the past several decades.

\section{Contemporary Global Union Activity}

Since the late $1960 \mathrm{~s}$, the program of the non-communist international trade union movement has developed from an exclusive concern for trade union rights into a call for a regulated global economy broadly along Keynesian lines. In 1969 ICFTU (and perhaps others) began issuing statements outlining the threat that unregulated global enterprises posed to union bargaining power through the ability of transnational corporations (TNCS) to "exploit international labour cost differentials" (Willatt, 1974: 11). In 1973 international trade union leaders met in Chile to discuss concerns about TNCs. It was argued that the international labour movement needed to confront the ability of TNCs to "play off one group of workers against another... by transferring production from one country to another" (Willatt, 1974: 9). As is illustrated below, from the 1970s on, the ICFTU and affiliated GUFs have expanded and intensified their activity in the economic, political and

4 Stevis suggests that the WFTU suspended its operations in the mid 1990s; however, the organization appears to have a functioning web site and held its last congress in 2005. See Stevis (1998). 


\section{A Most Curious Lack of Curiosity: Global Unions as the Missing Link in Labour Movement Studies}

civil society spheres in an effort to confront the growing power of transnational capital.

\section{Global Bargaining}

In 1989, the International Union of Food, Agricultural, Hotel, Restaurant, Catering, Tobacco, and Allied Workers' Association (IUF) signed an agreement with the French corporation MNE Danone which recognized basic union rights. Shortly thereafter, the International Union of Food, Agricultural, Hotel, Restaurant, Catering, Tobacco and Allied Workers' Association (IFBWW) signed an agreement with IKEA that is premised on ILO standards and provides for an annual joint review of labour-management relations. Another early agreement reached was between the International Federation of Chemical, Energy, Mine and General Workers' Union (ICEM) and Statoil, the Norwegian oil TNC, which outlined a protocol for unionization campaigns (ICFTU, 1999a: 66). Such agreements have come to be known as "international framework agreements" (IFA), and generally cover basic union and human rights, as defined by ILO and UN statutes, leaving wage rates and working conditions to local bargaining. Despite the limited nature, and perhaps limited utility, of IFA, they continue to be pursued by a number of the GUFs.5 Between 2000 and 2005 approximately 50 have been negotiated between TNCs and five of the largest GUFs (Sonczak, 2007).

The standardized collective agreements between the International Transport Workers' Federation (IFT) and the International Maritime Employers' Committee (IMEC), signed in 2000, are notable exceptions to these weak agreements. Unlike the Framework Agreements pursued by other Global Union Federations, these agreements establish the pay and basic working conditions for at least $27 \%$ of seafarers, a respectable percentage given the overall decline of union density noted across the globe (Lillie, 2004). However, it is far from a "standard" agreement as the IFT was unable to secure uniform wages and settled for wage agreements based on "Total Crew Cost," allowing "more flexibility to unions and employers in adapting to local conditions, while still preventing inter-union wage competition" (Lillie, 2004: 52).

It is clear that establishing global contract standards was a long battle both with employer groups and affiliates to the IFT. Divisions in the 1970s arose particularly between the ITF leadership, dominated by union representatives from the advanced capitalist countries and those from South and East Asia over what the National Union of Seafarers of India (and others, no doubt) saw as Northern protectionism. However, the ITF continued its internal campaign to build consensus amongst ITF affiliates. These internal negotiations were often hampered by the attempts of the IMEC to incite unions from India and the Philippines to break with the ITF. However, the entrance of seafarers from the former Soviet Union and Eastern bloc countries, which threatened to depress the wages of South and East Asia workers, further appears to have motivated these workers to sign on to the

5 For more positive assessments of Framework agreements, see Fairbrother and Hammer (2005), Riisgard (2005), and Wills (2002). 
idea of global negotiations (Lillie, 2004).

\section{Global Regulation}

Generally, ICFTU activities have focused on the pursuit of regulatory structures that will enhance GUF bargaining power. The initial campaign undertaken in the 1970s was to promote the adoption of codes of conduct which would bind the TNC to the relevant ILO conventions, force TNCs to publish an account of "wage rates and social conditions" in their various enterprises, "make significant contributions to the progressive development of the socio-economic structure in developing countries," engage in social dialogue with government and labour about "national economic and social objectives" and develop company-wide works councils (Willatt, 1974: 56). In 1976, an affiliate of Global Unions, the Trade Union Advisory Committee to the OECD (TUAC)6 was successful in having the OECD adopt "Guidelines for Multinational Enterprises" (Weinberg, 1978: 60-61). The following year the ILO adopted the "Declaration of Principles Concerning Multinational Enterprises and Social Policy."7 Both measures reaffirmed the right of states to set policy and outlined some basic "responsibilities" for TNCs, but there was no mechanism adopted to enforce such a code.

Negative publicity in the 1990s around the use of child labour led a number of companies involved in the production of athletic wear to adopt corporate codes of conduct. The pressure for the adoption of codes of conduct came largely from FIFA, the world governing body for football/ soccer (ICFTU, 1999a), pressure which was generated by a campaign targeting FIFA. 8 By the late 1990s, a number of TNCs had adopted many of the principles of the OECD guidelines and a number of ILO Declarations into their own corporate codes of conduct (OECD, 1998). An entire industry has emerged around advising companies on such codes and monitoring compliance. Yet even as the ICFTU pursued this strategy, it was made clear that Global Unions leaders were, and continue to be, far from satisfied with the situation. GUF leaders have suggested that such codes of conduct are, in many cases, "worse than useless, being mere public relations exercises without substance" (ITGLWF, 2006a). 9

ICFTU policy on how to create a regulatory framework within which the Global Union Federations could more effectively operate shifted in the 1990s from a call for voluntary codes of conduct to a demand that 'workers' rights' clauses be attached to trade agreements. Such standards, based upon ILO Declarations, would theoretically protect trade union rights, including the right to organize and bargain, establish a minimum age

6 TUAC emerged from the Trade Union Advisory Committee to the European Recovery Program, established in 1948 (TUAC, 2007).

7 A copy of the guidelines can be found at http://www.oecd.org/dataoecd/56/36/1922428.pdf

8 For an outline of FIFA's perceived role in preventing child labour see their policy statement: http://www.fifa.com/en/fairplay/humanitariansection/0,1422,3,00.html

9 See also ITGLWF (2006b). 


\section{A Most Curious Lack of Curiosity: Global Unions as the Missing Link in Labour Movement Studies}

for employment, prohibit discrimination against women in employment, and forbid the use of forced labour (ICFTU, 1999a). Such clauses are part of an over-all vision of extending globally the protections won largely during the post-war period in the advanced capitalist countries.

The Global Unions leadership argue that essential for such protections to be meaningful is the "effective governance of the global economy," which would include "systems of corporate governance" (ICFTU, 2003), and a "new financial order" to put in place international agreements on capital taxation and taxation on currency speculation, such as the Tobin Tax, in order to stabilize the world's economy (ICFTU, 1996). The creation of the WTO in 1995 was seen by many within Global Unions as "a window of opportunity" (ICFTU, 1999a: 52). At the meetings in 1997 and 1998 the ICFTU produced reports on "core labour standards" in the hope of "encouraging debate" with the aim of having the WTO not only include such standards in its agreements but also expand its role in monitoring member countries compliance (ICFTU, 1999a: 52-53). This has yet to materialize.

A further illustration that international trade unions have developed a more comprehensive position than their earlier attempts at regulating TNC activity can also be seen in the ILO "Decent Work Agenda." The agenda largely reflects the concerns of ICFTU-affiliated union groups about the effects of neoliberal economic globalization on workers and has as its goal the establishment of "a global social safety net" (ICFTU Online, 2000b). The most comprehensive and ambitious sounding initiative to emerge from the ILO, the Decent Work agenda, seeks to "improve the conditions of all people, waged and unwaged, working in the formal or informal economy, through efforts at re-regulation and the expansion of social and labour protections" (Vosko, 2002: 26). Such a position seems to indicate a broadening of the perspective of ILO labour delegates beyond their memberships.

As part of expanding its concerns beyond the narrow confines of waged and often unionised workers, the ILO has initiated projects relating to poverty reduction, economic capacity building, democratisation and 'fundamental' rights in over 20 countries (ILO, 2005), again with the support of trade union representatives. The focal point of its campaigns on social protection and the promotion of basic rights is the Social Declaration (1998). Yet it is interesting to note, as Vosko does, that this campaign is limited to promoting only four of its two hundred declarations: those relating to freedom of association and collective bargaining; the elimination of child labour; the abolition of forced labour; and the elimination of workplace discrimination (Vosko, 2002: 27-29).

It must further be noted that the approach to promoting labour and human rights has not changed. Without a mechanism of enforcement, global regulations developed by the ILO and promoted by ILO supporters are of little utility; the ILO has no more leverage 
than moral persuasion through the issuance of annual reports that follow the progress of countries in meeting their ILO charter obligations. As Vosko points out, targeting states for embarrassment does little to "enable states to challenge global capital collectively" (2002: 29-30). This profound limitation is why, despite supporting the Decent Work program vociferously, the ICFTU continues to pursue mechanisms that might bind states to the international agreements they sign through the WTO.

\section{New Relationships}

\section{A 'New' International}

In November 2006 two new international union organizations were created, the International Trade Union Confederation (ITUC), and the Council of Global Unions that emerged out of a major reorganization of the international trade union movement. ITUC is the result of the legal dissolution of both the WCL and the ICFTU for the purposes of uniting under one organization. The Council, created at the first meeting of ITUC, is a deliberative body involving the GUFs, ITUC, and TUAC.

The nature of these changes appear open to debate. For ITUC leaders and staff, this is a major step in the formation of a powerful global trade union movement. Guy Ryder, ITUC General Secretary and former General Secretary of the ICFTU, sees an organization more capable of developing and executing "strategies to counter those of capitalism" (Peninsula Online, 2007). ITUC staff have similarly made positive assessments, suggesting that it is an "opportunity to renew the commitment of the international trade union movement to defending human and trade union rights" (Kuczkiewicz, 2007). Waterman, a long time observer of the ICFTU and former WFTU staff person, is more sceptical. He argues that the ITUC is "largely (an) administrative merger" between two trade union organizations of the "social-reformist tradition" based out of Western Europe (Waterman, 2007).

Unification has been an issue for the ICFTU leadership since its inception in 1949. When the International Federation of Christian Trade Unions dropped its explicitly Christian framework and renamed itself the World Congress of Labour in 1968, the ICFTU approached the organization formally, but was rebuffed, largely, it appears, out of the concerns raised by member organizations that they would be "subsumed" by the larger organization (EIRR, 2006: 27). However, WCL's transition from an explicitly confessional organization to one inspired by "humanist, ethical and moral goals" (EIRR, 2006: 27) allowed the relationship between the WCL and the ICFTU to remain largely cordial. By the 1990s there was a great deal of campaign coordination between the WCL and the ICFTU, with the two organizations speaking "with a single voice" at international forums (EIRR, 2006: 28). 


\section{A Most Curious Lack of Curiosity: Global Unions as the Missing Link in Labour Movement Studies}

While there is little public record of unity talks prior to 2004, it is clear from internal ICFTU documents that this was discussed formally by ICFTU leaders at least as early as 1998 (ICFTU, 1999a; 1999b). In 2000, the ICFTU "Millennium Review" instructed the Executive Board to review "the ICFTU's structural relationships and means of cooperation, both within our own structure and with other international trade union organizations" (ICFTU, 2000). This was followed up by General Secretary Ryder calling upon "those outside the ICFTU" to participate in a review of international trade union organization and strategy (ICFTU, Online, 2000a). In 2003, ICFTU Secretary General Ryder used a meeting of the ETUC to publicly call for the unification of the ICFTU and the WCL (EIRR, 2006: 7). The following year ICFTU delegates approved formal unification talks with WCL "and other democratic and independent trade union centres not currently affiliated to either" (EIRR, 2006: 28). It is clear from ITUC's 2006 membership list that at least some former WFTU members have decided to join the new organization, or at least a number of workers who would have been members of WFTU unions have formed new organizations since 1989, through which they have joined ITUC.10 In September 2005 a joint statement was issued by the Secretary Generals of the WCL and ICFTU that both organizations agreed to recommend to their members dissolution of their respective organizations and the creation of a new organization, a decision, they said "reflecting a unanimous wish to strengthen trade unionism in the face of unfettered globalization" (EIRR, 2006: 28).

Yet the vote at the subsequent WCL Congress was far from unanimous with "at least 14 affiliates" voting against dissolution (Gumbrell-McCormick, 2006: 4). How many of those unions will decide to join the new congress remains to be seen. The "unity" resolution passed at the WCL Congress also contained a resolution to establish a "World Social Assembly" that was pushed by the internal caucus Coalition for Social Development, made up of a small number of WCL affiliates from Europe. This forum is intended "as a meeting place for reflection and deepening of the (sic) value-based (read: spiritual/ religious) trade unionism in the world" (WCL, 2006: 7). Angès Jongerius, president of the Dutch FNV, has publicly expressed the hope that the organization would "soon fade away" (GumbrellMcCormick, 2006: 5). Jongerius' comment hints at the divisions between ICFTU and WCL affiliates at the national level, which undoubtedly hampered previous attempts at unification.

Waterman (2007) highlights a number of potential struggles arising out of what he refers to as a "merger," an observation supported by reports from these organizations of difficult negotiations (ICFTU Online, 2004a; ICFTU Online, 2004b). Divisions between former WCL and ICFTU affiliated unions and federations at the local and national level undoubtedly contributed to the difficult negotiations over the mergers between regional organizations that are supposed to occur. Furthermore, tough questions remain unanswered about the relationship between the new regional organizations and the Executive Board of the ITUC. 
WCL-affiliated regional bodies historically maintained a great deal of independence from the WCL Confederal Board. This was not the case with the ICFTU and its regional organizations In the case of the Americas, negotiations are further complicated by the fact that the ICFTU organization ORIT encompasses North and South America, while the WCL affiliate CLAT, represents Latin American unions exclusively. Nonetheless, these negotiations have succeeded in producing regional organizations in the Americas, Asia/ Pacific, Africa, and Europe (ITUC, 2007a; 2008a).

At the time of the merger/ amalgamation/ dissolution of the ICFTU and WCL, negotiations over the merger of WCL trade specific caucuses and the Global Union Federations were anticipated to be equally difficult. As the nine 'international trade federations' (caucuses, really) within the WCL lacked autonomy, they are relatively weak compared to the Global Union Federations (GUF)11 whom, while closely affiliated to the ICFTU, have always had total autonomy.12

\section{Relationships with Other Social Movement Organizations}

Negotiations around the ILO Decent Work Agenda appear to illustrate a shifting attitude amongst international trade union leaders towards other social movement organizations also concerned with labour issues. Pointing to the coalition of labour as well as NGOs concerned with women and other marginalized workers, Vosko argues that certain "facets" of the Decent Work initiative are the product of "a growing counter-hegemonic presence inside the ILO and especially at its margins" which involves a larger group than the representatives of the international trade union movement (2002: 20). Research conducted by Vosko (2002) suggests that the Convention Concerning Home Work, central to the Decent Work initiative, would not have survived a campaign against it by the Employers' Group if it were not for a coalition of groups, often at odds with one another, that came together in a coordinated defence of the convention, including the ICFTU, unions representing workers in the informal economy and women's groups.

Historically, trade unions have limited their participation in social dialogue to those tripartite arrangements involving representatives of capital, labour and the state. Such a coalition, as described by Vosko, represents a relatively new approach for international trade union leaders in their dealings with civil society groups. Most likely it is a product

11 These were formerly known as the International Trade Secretariats. The 10 GUF are Education International; International Federation of Building and Wood Workers; International Federation of Chemical, Energy, Mine and General Workers' Union; International Federation of Journalists; International Metalworkers' Federation; International Textile, Garment and Leather Workers' Federation; International Transport Workers' Federation, International Union of Food, Agricultural, Hotel, Restaurant, Catering, Tobacco and Allied Workers' Association; Public Services International; Union Network International. As accessed via www.globalunions.org.

12 During the postwar split, the International Trade Secretariats that existed at the time opted to align themselves with the ICFTU, rather than the WFTU over the issue of autonomy from the central organization. 


\section{A Most Curious Lack of Curiosity: Global Unions as the Missing Link in Labour Movement Studies}

of re-evaluating strategy in the light of failed attempts at traditional social dialogue, the changing nature of social dialogue, and the debates over social movement unionism happening within member organisations such as the AFL-CIO, CLC, and COSTAU.13

In addition to tripartite deliberations at the ILO and lobbying other UN institutions, international union leaders have traditionally participated in the World Economic Forum, where they call on business leaders to engage in "fair and balanced dialogue," adhere to ILO standards and recognise international unions through framework agreements (Global Unions Group, 2004: 3). Although Global Unions and many of its affiliates continue to partake in the WEF, they have spent more time in recent years engaging in dialogue with other social movement organizations at events such as the World Social Forum (WSF).14 Waterman reports from the 3rd WSF that there appears to be "a growth and deepening of the relationship" between the "traditional international union institutions" and other WSF participating groups (Waterman, 2004: 228). At the time of the WSF3, there were "about a dozen inter/ national union representatives on the International Council" of the WSF, and a number of Global Union leaders, including the General Secretary of the ICFTU attended that year's event either on panels or as participant/ observers "quietly testing the waters" (Waterman, 2004: 228).

This increased presence at WSF comes shortly after the 'Bangkok Roundtable' meetings between international trade union leaders and NGO workers held in 2001 and 2002. These meetings were organized by the Friedrich Ebert Foundation and Focus on the Global South with the intention of discussing the relationship amongst those challenging neoliberal globalization (Solidar, 2001; Schweißhelm, 2002). According to internal ICFTU documents, this was not the first time its leadership had conducted such meetings (ICFTU, 1999c). Predictably, the focal point for both trade union leaders and the broader social justice movement is opposition to the liberalisation of the global economy, the project of privatising basic services, and the deregulation of formally protected industries. All generally agree as well that the quasi-state organizations, the World Bank, IMF and the WTO are undemocratic, lacking in transparency and have no popular support for their policies.

However, the major trade unions at the global level differ from a number of other civil society groups involved in opposing neoliberal globalization in their approach to IFIs, as well as their attitudes towards industrialization and particularly, their attitudes towards export oriented economic activity. The union organizations affiliated with Global Unions also differ from other labour groups in their approach to organizing and campaigning. Beiler notes that at the Nairobi 2007 WSF, delegates from the ITUC sought consensus around support for the Decent Work Agenda, while smaller, more radical union groups

13 For an examination of social dialogue, see Fashoyin (2004).

14 In fact, unification meetings between leaders are said to have happened at the Forum. See Waterman (2007). 
argued that efforts would be better spent focusing on inter-organizational cooperation and "the development of common aims and objectives" (Beiler, 2007: 5).

Waterman (2004: 228) argues that many of the traditional international union leaders on WSF panels appeared quite willing to "come to terms" with what he refers to as the Global Justice and Solidarity Movement (GJ\&SM) and recognised that the latter "has the appeal, dynamism, public reach and mobilizing capacity that they themselves both seriously lack and desperately need." However, it remains to be seen whether or not the GJ\&SM will accept the Global Unions reformist strategy of making capitalism 'decent' or whether the movement will seek to propose a new, more 'utopian' project that may or may not involve traditional unions.

\section{Questions}

Two clear arguments emerge from the above outline of the changing strategy of the international trade union organizations. First, the ITUC and the Council of Global Unions are far from irrelevant global actors. They are the largest and most representative bodies of organized working people in the world. This is not to say that the nature of that representation is without problems. Indeed it could be argued that the ITUC does not represent working people so much as the representatives of those workers who are union members. However, it must be noted that issues outside of the traditional trade union gambit, particularly issues relating to workers in the informal sector, are getting far more attention at ITUC meetings (Gumbrell-McCormick, 2006). While this could be dismissed as little more than convention talk, it does appear from positions taken at the ILO that such issues are being taken up by ITUC leaders (ITUC, 2007b; 2008b). How serious the leadership of ITUC takes such issues, and how much effort these issues receive compared to purely 'trade union' issues, will only be known by the ongoing study of its actual campaigns.

What I see as an increasing relevancy of ITUC and the Council is also directly related to the increase in its engagement with the broader global social justice movement. It is clear that the leadership of these organizations are pursuing new relationships with groups outside of the trade union movement. But we must ask, as Waterman (2004) does, "what kind of relationship is developing here?" Is the recent attention of the Council of Global Unions to the WSF merely a tactic to get support for ITUC activities at UN forums, or does it represent a sincere attempt by trade union leaders to seek out new influences and ideas? Is it conceivable that these new relationships could be the seeds of a social-movement unionism, as suggested by Moody (1997)? Could any global labour organization, regardless of how broad its mandate, meaningfully represent the needs of a highly stratified global working class? 


\section{A Most Curious Lack of Curiosity: Global Unions as the Missing Link in Labour Movement Studies}

Secondly, it is also clear from the changes over the past decade that the institutions of the international trade union movement can no longer be dismissed as Cold-war relics. It is quite obvious that a shift has occurred where confronting other labour organizations has given way to confronting capital. This shift has been accompanied by another shift in the platforms put forward by the ITUC and its affiliated organizations. This shift has been from a very 'bread and butter' trade unionism, traditionally associated with the American AFL-CIO and its strong position in the ICFTU, to a more comprehensive social democratic program that addresses issues beyond collective bargaining. However, the causal mechanisms that led to this shift have yet to be explained. Is this the product of a push from southern unions who have generally been at the margins of ICFTU strategy? Or, did the end of the Cold-war bring an end to the dominant role of the AFL-CIO, and the ascendance of the more social-democratic oriented European Union federations?

Clearly, how questions around the mergence of a more consolidated, and perhaps powerful, international trade union movement committed to social-democratic policies and strategy will be approached differently by left academics. Socialism is by no means a unified ontological position. Thus different socialists will frame and explore these questions through different theoretical and methodological frameworks.

For those who see utility in trade union activity, the pursuit of social-democratic reforms, and the regulation of capital a number of questions about the institutions needed for meaningful wealth redistribution need to be answered. For example, if it is assumed that global collective bargaining presents an effective means of redistributing wealth, what conditions are necessary for the successful prosecution of this strategy? Lillie suggests that the ITF was able to establish collective bargaining beyond framework agreements is related to ITF affiliates having "little or no independent bargaining strength," and that this pushed affiliates to accept the ITF strategy of centralized bargaining (2004: 63-63). However, the declining power of national unions vis a vis TNCs is broadly accepted as existing across industrial sectors, which suggests that this is not a complete answer. Surely there are structural mechanisms that have contributed to the ITF success that do not exist in other industries. Is it really, as Lillie implies, simply a matter of solidarity amongst national union leaders?

Both collective bargaining and wealth redistribution lead to questions of what kind of regulatory mechanisms must exist for this to occur. Harvey suggests that it is not inconceivable that the current instability of the capitalist system may lead to a "new, New Deal" (Harvey, 2005: 209). Clearly, this fits within the demands being made by ITUC at the ILO and elsewhere. What is less clear, however, is how such regulation might work at the global level. Surely a global state is a long way off. What regulatory mechanism could be possible in the meantime? 
For those who see attempts at regulating capitalism akin to putting lipstick on a pig, questions will most likely be framed in terms of how this growing monolith within the global labour movement can be marginalized by a more radical voice, or pushed to a more radical position from within. North American labour history illustrates that the greatest gains for working people under capitalism have occurred when trade union leaders faced challenges from more radical labour activists (Keeran, 1979; Manley, 1992; Stepan-Norris, 2003). Although it has been argued here that the WFTU is a far less dynamic organization than the ITUC, this does not suggest that a more radical class politics, as exemplified by WFTU members, could not infuse a more dynamic political framework through which the demands and aspirations of labour could be established, organized and given voice.

\section{Conclusion}

The argument of this paper is that a lacuna continues to exist despite the renewed interest in the related but so far distinct bodies of literature on trade union revitalization and labour internationalism. The first body of literature remains largely local and national in scope. Such "methodological nationalism" (Beck and Willms, 2004) is increasingly problematic in trade union studies as the need to analyse the conflict between capital and labour becomes more important.

Traditionally, the study of organized labour has focused on the local and the national because people's struggles as workers are still largely experienced as local phenomena. Picket lines, strike votes, labour-management meetings, and marches on parliaments all happen in a particular place. Furthermore, it is the local and national context where the power of the labour movement is seen to be grounded historically. Trade unions and other labour organizations organized people as unionized workers with the potential to withhold their labour power and as voters with the power to influence legislation.

In the post-war period, labour in the advanced capitalist countries was able to secure a number of important concessions from capital and the state. But the success of trade unions to establish a role under the regulatory regime of Fordism was directly related to the needs and limitations of nationally based and bound industrial capital. The crisis of Fordism in the 1970s (Dunford, 2000; Hammes and Wills, 2005; Lipietz, 1997), and the concurrent development of transportation and communications technologies which reduced the transaction costs of global economic activity (Dickens and Hall, 2003), has increased the ability of capital to shift production and services around the world (IettoGillies, 2002). This increases the competitive pressures felt by workers and decreases the power of local and national repertoires of class resistance. The nature of capitalist hegemony is currently being reshaped, at the global level by the emergence of a truly transnational capitalist class (Sklair, 2001). Thus the response of organized labour at the global level is of profound importance. 
The literature on labour internationalism largely focuses on the newly emerging networks of labour activists, rather than existing global unions. This can likely be attributed to the frustration experienced by labour movement scholars and activists with the failing ability of traditional unionism to counter global capital. Trade unions here are often presented as bureaucratically moribund and incapable of the changes deemed necessary to confront capital in a dramatically changed global political economy, although this has been challenged by some (Voss and Sherman, 2000). Given this general perception of trade unions, researchers have been keen to find new organizations that may present a way forward for labour in its ongoing confrontation with capital (Castree, 2002; Waterman, 2001; 2005).

Implicit here is a belief that international trade unions have been consigned to the dust bin of history. Such assumptions illustrate an inability to develop a dialectical understanding of history. Social institutions do not simply disappear. They are transformed by social pressures from outside forces and tensions generated within them. Eventually they are overwhelmed by history. But even then new institutions contain something of the old ones. Therefore, we can anticipate that at least some of the seeds of a new global labour movement can be found in the existing international trade unions. 


\section{REFERENCES}

Beck, Ulrich and Johannes Willms. 2004. Conversations with Ulrich Beck. Cambridge: Polity Press.

Braunthal, Julius. 1966. History of the International. London: Nelson.

Busch, Gary. 1983. The Political Role of International Trade Unions. London: MacMillan Press.

Carew, Andrew. 1984. "The Schism within the World Federation of Trade Unions: Government and Trade-Union Diplomacy." International Review of Social History. Vol. 29, No. 3, pp. 297-335.

Carew, Andrew, Michel Dreyfus, Geert Van Goethem, Rebecca Gumbrell-McCormick and Marcil van der Linden (eds.) 2000. The International Confederation of Free Trade Unions. M. van der Linden (ed.). New York: Oxford.

Castree, Noel. 2002. "Geographic Scale and Grass-Roots Internationalism: The Liverpool Dock Dispute, 1995-1998.” Economic Geography. Vol. 76, No. 3, pp. 272-93.

Chun, Jennifer Jihye. 2005. "Public Dramas and the Politics of Justice: Comparison of Janitors' Union Struggles in South Korea and the United States.” Work and Occupations. Vol. 32, No. 4, pp. 486-503.

Cole, G.D.H. 1953. A History of Socialist Thought, Vol. 2. New York: St. Martin's Press.

Dickens, Linda and Mark Hall. 2003. "Labour Law and Industrial Relations: A New Settlement?”In IndustrialRelations:Theory andPractice.P.K.Edwards (ed.).Malden: Blackwell Publishing, pp. 124-156.

Dunford, Michael. 2000. "Globalization and Theories of Regulation.” In Global Political Economy: Contemporary Theories. R. Palan (ed.). London; New York: Routledge, pp. 143-167.

EIRR. 2006. "International Union Confederation to Be Created." European Industrial Relations Review. Vol. 384, pp. 27-28.

Fairbrother, Peter and Nikolaus Hammer. 2005. "Global Unions: Past Efforts and Future Prospects.” Relations Industrielles/Industrial Relations. Vol. 60, No. 3, pp. 405-31. 


\section{A Most Curious Lack of Curiosity: Global Unions as the Missing Link in Labour Movement Studies}

Gamble, Andrew. 2007. Labour, the State, Social Movements and the Challenge of NeoLiberal Globalisation. Manchester: Manchester University Press.

Greenwood, John Henry and Sidney Webb. 1911. The Theory and Practice of Trade Unionism. London: A.C. Fifield.

Gumbell-McCormick, Rebecca. 2006. "From the Old Trade Union Internationals to the New: Commentary on the ICFTU/ITUC Congress, Vienna, 31.10-3.11.06." LabourStart, 08-11-2006.

Gumbrell-McCormick, Rebecca. 2004a. "The ICFTU and the World Economy: A Historical Perspective " in Labour and Globalisation: Results and Prospects. R. Munck (ed.). Liverpool: Liverpool University Press, pp. 34-51.

Gumbell-McCormick, Rebecca. 2004b. "The ICFTU and Trade Unions in the Developing Countries: Solidarity for Dependence?" In Unions in the 21st Century: An International Perspective, A. Verma and T. A. Kochan (eds.). New York: Palgrave Macmillan, pp. 179-190.

Hammes, David and Douglas Wills. 2005. "Black Gold: The End of Bretton Woods and the Oil-Price Shocks of the 1970s." Independent Review. Vol.9, No. 4, pp. 501-11.

Harvey, David. 2005. The New Imperialism. London: Oxford University Press.

ICFTU. 2003. "Democratizing Globalization: Trade Union Statement to 2003 WSF and WEF." http://www.icftu.org/displaydocument.asp?Index =991216994\&Language=EN

ICFTU. 1999a. "Building Workers' Human Rights into the Global Trading System". <http://www.icftu.org/www/english/els/esc199BWRGTS.pdf>.

ICFTU. 1999c. Report of the 15th Meeting of the Steering Committee (Elsinore, 24 November 1998). Elsinore: International Confederation of Free Trade Unions.

ICFTU Online. 2004a. “Making Solidarity Work - on the Road to Reform.” ICFTU Online/ 7/12/2004, http://www.icftu.org/displaydocument.asp ?Index=991221019\&Language $=\mathrm{EN}$

ICFTU Online. 2004b. “The Millennium Development Goals: The World's Trade Unions Need to Unite in the Global Anti-Poverty Campaign.” ICFTU Online 8/12/2004, http://www.icftu.org/displaydocument.asp?Index=991221088\&Language=EN 
ICFTU Online. 2000a. "The Millennium Debate - the review for change," ICFTU Online 7/4/2000, http://www.icftu.org/displaydocument.asp?Index=991209895\& Language $=\mathrm{EN}$

ICFTU Online. 2000b. “The Future Shape of the Trade Union Movement,” ICFTU Online, $10 / 5 / 2000$.

ICTUR (International Centre for Trade Union Rights). 2005. Trade Unions of the World. London: John Harper Publishing.

Ietto-Gillies, Grazia. 2002. Transnational Corporations : Fragmentation Amidst Integration Grazia Ietto-Gillies. London: Routledge.

ITGLWF. 2006a.'Regulation the Only Way to Stop Labour Rights' Abuses in Supply Chains." http://www.global-unions.org/displaydocument.asp?DocType=PressRelease \&Index=991210488 \&Language $=$ EN.

ITGLWF. 2006b. "Social Compliance a Costly Cosmetic Exercise, Says Global Union Federation.” http://www.itglwf.org/displaydocument.asp?DocType=Press\&Language $=\&$ Index $=1565$.

ITUC. (International Trade Union Confederation). 2008a. "New Unified ITUC Regional Organisation Founded.” ITUC Online. 31/03/08.

ITUC. 2008b. "Protection of Domestic Workers: The ITUC Supports Proposed ILO Convention.” ITUC Online. 028/130208.

ITUC. 2007a. "Founding of the PERC Gives Hope to European Workers." ITUC Online. 19/03/07.

ITUC. 2007b. "Global Trade Union Body Calls for International Convention to Protect Domestic Workers.” ITUC Online. 188/311007.

Keeran, Roger R. 1979. "Communist Influence in the Automobile Industry, 1920-1933.” Labor History. Vol. 20, No. 2, pp. 189-225.

Lillie, Nathan. 2004. "Global Collective Bargaining on Flag of Convenience Shipping." British Journal of Industrial Relations. Vol. 42, No.1, pp. 47-67.

Lipietz, Alain. 1997. "The Post-Fordist World: Labour Relations, International Hierarchy and Global Ecology." Review of International Political Economy. Vol. 4, No. 1, pp. $1-41$. 


\section{A Most Curious Lack of Curiosity: Global Unions as the Missing Link in Labour Movement Studies}

Lorwin, Lewis Levitzki. 1953. The International Labor Movement: History, Policies, Outlook. New York: Harper.

Manley, John. 1992. "Communists and Autoworkers: The Struggle for Industrial Unionism in the Canadian Automobile Industry, 1925 - 1936." In Canadian Working Class History: Selected Readings. L. S. MacDowell and I. W. Radforth (eds.). Toronto: Canadian Scholars' Press, pp. 481-505.

Milner, Susan. 1988. "The International Labour Movement and the Limits of Internationalism: The International Secretariat of National Trade Union Centers, 1901-1913.” International Review of Social History. Vol. 33, pp. 1-24.

Moody, K. 1997. “Towards an International Social-Movement Unionism.” New Left Review. Vol. 225, pp. 52-72.

Munck, Ronaldo. 'Globalization, Labor and the 'Polyani Problem.' Labor History, Vol. 45, No. 3, pp. 251-269.

Munck, Ronaldo and Peter Waterman. 1999. Labour Worldwide in the Era of Globalization: Alternative Union Models in the New World Order. London: Macmillan.

Peninsula Online. 2007. "Trade Unions Meet to Create New Body.” Peninsula Online, 11/1/2006, http://www.thepeninsulaqatar.com/Display_news.asp?section =business_ news\&month=november2006\&file=business_news2006110132418.xml

Riisgard, Lone. 2005. "International Framework Agreements: A New Model for Securing Workers Rights?” Industrial Relations. Vol. 44, No. 4, pp. 707-737.

Schevenels, Walter. 1956. Forty-Five Years, 1901-1945; International Federation of Trade Unions, a Historical Précis. Brussels: Board of Trustees, International Federation of Trade Unions.

Sonczak, André. 2007. "Legal Dimensions of International Framework Agreements in the Field of Corporate Social Responsibility.” Industrial Relations. Vol. 62, No. 3, pp. 466-91.

Stepan-Norris, Judith and Maurice Zeitlin. 2003. Left Out: Reds and America's Industrial Unions. Cambridge: Cambridge University Press. 
Stillerman, Joel. 2003. "Transnational Activists Networks and the Emergence of Labor Internationalism in the NAFTA Countries." Social Science History, Vol. 27, pp. 577601.

Stevis, Dimitris. 1998. "International Labor Organizations, 1864-1997: The Weight of History and the Challenges of the Present." Journal of World Systems Research. Vol. 4, No. 1, pp. 52-75.

Sverke, Magnus. 1997. The Future of Trade Unionism: International Perspectives on Emerging Union Structures. Aldershot: Ashgate.

TUAC. 2007. Online. http://www.tuac.org/en/public/tuac/index.phtml

Turner, L. 2005. "From Transformation to Revitalization - a New Research Agenda for a Contested Global Economy.” Work and Occupations. Vol. 32, No. 4, pp. 383-99.

Waterman, Peter. 2007. "Virtually Invisible: The International Union Merger." International Union Rights Journal. Vol. 13. No. 3, pp.

Waterman, Peter. 2005. "The Forward March of Labour (and Unions?) Recommenced: Reflections on an Emancipatory Labour Internationalism and International Labour Studies 1." Antipode. Vol. 37, No. 2, pp. 208-18.

Waterman, Peter. 2004. "Adventures of Emancipatory Labour Strategy as the New Global Movement Challenges International Unionism.” Journal of World Systems Research. Vol. 10, No. 1, pp. 217-53.

Waterman, Peter. 2001. Globalization, Social Movements, and the New Internationalisms. London: Continuum.

Waterman, Peter and Jane Wills (eds.). 2001. Place, Space and the New Labour Internationalisms. Oxford: Blackwell.

Weinberg, P. J. 1978. European Labor and Multinationals. New York: Praeger Publishers.

Wills, Jane. 2002. "Bargaining for the Space to Organize in the Global Economy: A Review of the Accor--IUF Trade Union Rights Agreement." Review of International Political Economy. Vol. 9, No. 4, pp. 675-701. 
Windmuller, John P. 1980. The International Trade Union Movement. Boston: Kluwer.

Windmuller, John P. 1969. Labor Internationals: A Survey of Contemporary International Trade Union Organizations. Ithaca, N.Y.: New York State School of Industrial and Labor Relations, Cornell University. 